\title{
Relationship Between Mountain Climbing and Protein in Urine
}

\author{
Muhammad Imran Qadir and Sania zafar* \\ Institute of Molecular Biology and Biotechnology, Bahauddin Zakariya University Multan, Malaysia
}

Submission: October 21, 2019 , Published: October 28, 2019

*Corresponding author: Sania zafar, Institute of Molecular Biology and Biotechnology, Bahauddin Zakariya University Multan, Malaysia

\begin{abstract}
This study explore the relationship between the mountain climbing and the protein in urine. mountain climbing is classified into two types and the level of problem is seasonal. In summer climbers utilize their abilities while in winter snow is an additional challenge. Presence of kidney in urine is known as proteinuria.it indicated the abnormal functioning of the kidney and show that the kidney not perform well. this study show the relation of the protein in urine and the people who do mountain climbing and the who do not do mountain climbing.
\end{abstract}

Keywords: Mountain climbing; Proteinuria; Nephrotic syndrome; Correlation

\section{Introduction}

Mountain climbs are grouped by two evaluating frameworks in Britain, which between them portray both the general trouble and introduction of a course, and the level of trouble in making the hardest proceed onward the ascension (the core). In "summer conditions", climbers utilize their abilities and specialized hardware to enable them to finish risings on normal shake includes on mountainsides. In "winter conditions", snow and ice include an additional challenge, and climbers must utilize ice tomahawks and crampons to finish their picked course. Winter moving in Scotland is normally a blend of snow, ice and exposed shake climbing. The individuals who are gifted at winter climbing might be less talented at summer climbing (and bad habit versa), and inclinations may well differ between seasons for a given person. Be that as it may, climbers' valuation for courses reaches out past their specialized evaluating to incorporate perspectives, for example, length of trip, quality and level of swarming on a course. One may in this manner consider singular trips as various packs of a given arrangement of characteristics, in spite of the fact that it might be hard for the specialist to totally portray a specific trip utilizing this set. Climbers settle on decisions from the arrangement of all ascensions in Scotland in choosing where to go on a specific outing: a characteristic method to display this decision issue is in this manner to utilize arbitrary utility hypothesis [1].

The presence of protein in the pee is called proteinuria. The nearness of the protein in the urine is the sign of kidney issues. The kidney channels the proteins and under ordinary conditions don't enable the protein to go through the channels. On the off chance that there is the nearness of protein in pee it demonstrates that the kidney channels are not functioning admirably [2]. Protein is available in the pee of each individual. The principle protein present is egg whites. Kidney channels the protein and returns back to the body. In the event that the protein is available in the urine it demonstrates that the kidneys are not functioning admirably and this condition is called Nephrotic disorder. The nearness of the protein in pee might be because of various reasons like the circulatory strain and diabetes. In some cases the protein might be available because of the utilization of medicine, poisons injury and so forth. Ordinarily there are no particular side effects of protein in pee however the pee appearance might be foamy and show edema [3].

\section{Materials and Method}

\section{Material}

For the performing of this test we needed test strips, urine specimens, watch, gloves, special container for the collection of urine, tissue paper, wastage bags.

\section{Project designing}

The individuals are chosen for the test. We chose the peoples who do mountain climbing and the general peoples who don't do mountain climbing. Their urine was collected and tried for the glucose in the urine. All individuals chose for the test were taken from the Institute of Molecular Biology and Biotechnology Bahauddin Zakariya University Multan. 


\section{Test for protein in urine}

At firstly, we are take urine samples for urine test with the help of strip dip method. Urine is collected in the urine collecting bottles from the individuals. Take fresh urine sample from the peoples and then dip the strip for approximately 2 seconds with full of its length and different colour shows on the strips. Then come this strips near the test bottle in such a way that all tests are clearly determined. this strip has 10 different patches which are chemically reacted, now dip this strip in urine and then removed. Each patch has its particular colour. If the protein in urine is present in urine then it show the patch and different colour. The shade is occur and the colour is noted on the note book. Then discarded all this materials which is used and wash the hands .After the estimation of the protein level and the outcomes were contrasted which shows the connection between the mountain climbers and protein in urine.

\section{Statistical Analysis}

To figure out at the after effects of tests M-state Software was utilized. The outcomes were given in the table and chart was attracted to explain the relationship.

\section{Result and Discussion}

The result show the relation ship between the urine protein and the mountain climbing the people who do mountain climbing has the lowest value of urine protein . positive value of urine protein in males is $20 \%$ which is very smallest and the negative value of urine protein in males is $80 \%$. on the other hand the people who do not like mountain climbing has the positive value of urine protein is $66.66 \%$ and the negative value is $33.34 \%$ in males. these values are aproximately same in the females. this relationship show that mountain climbing effect the urine protein (Table 1).

Table 1: relation between urine protein and mountain climbing in males and females.

\begin{tabular}{|c|c|c|c|c|}
\hline \multirow{2}{*}{ Gender } & \multicolumn{2}{|c|}{ Do Mountain Climbing } & \multicolumn{2}{|c|}{$\begin{array}{c}\text { Do Not Do Mountain Climb- } \\
\text { ing }\end{array}$} \\
\hline & $\begin{array}{c}\text { Urine } \\
\text { Protein } \\
\text { Positive }\end{array}$ & $\begin{array}{c}\text { Urine } \\
\text { protein } \\
\text { Negative }\end{array}$ & $\begin{array}{c}\text { Urine Pro- } \\
\text { tein Positive }\end{array}$ & $\begin{array}{c}\text { Urine Protein } \\
\text { Negative }\end{array}$ \\
\hline Male & $20 \%$ & $80 \%$ & $66.66 \%$ & $33.34 \%$ \\
\hline Female & $26.66 \%$ & $73.43 \%$ & $65.39 \%$ & $34.61 \%$ \\
\hline
\end{tabular}

\section{References}

1. Briggs D, Stebbins R (2014) Solo ice climbing: An exploration of a new outdoor leisure activity. Journal of Outdoor Recreation, Education, and Leadership 6: 55-67.

2. http://www.kidneyfund.org/kidney-disease/kidney-problems/ protein-in-urine.html.

3. https://www.nhs.uk/Livewell/Kidneyhealth/Documents/ protein $\% 20$ in $\% 20$ urine.pdf

\section{Your next submission with Juniper Publishers will reach you the below assets}

- Quality Editorial service

- Swift Peer Review

- Reprints availability

- E-prints Service

- Manuscript Podcast for convenient understanding

- Global attainment for your research

- Manuscript accessibility in different formats

( Pdf, E-pub, Full Tsext, Audio)

- Unceasing customer service

Track the below URL for one-step submission https://juniperpublishers.com/online-submission.php 